This PDF is a selection from a published volume from the National Bureau of Economic Research

Volume Title: Fiscal Policy after the Financial Crisis

Volume Author/Editor: Alberto Alesina and Francesco Giavazzi, editors

Volume Publisher: University of Chicago Press

Volume ISBN: 0-226-01844-X, 978-0-226-01844-7 (cloth)

Volume URL: http://www.nber.org/books/ales11-1

Conference Date: December 12-13, 2011

Publication Date: June 2013

Chapter Title: The Role of Growth Slowdowns and Forecast Errors in Public Debt Crises

Chapter Author(s): William Easterly

Chapter URL: http://www.nber.org/chapters/c12640

Chapter pages in book: (p. 151 - 173) 


\title{
The Role of Growth Slowdowns and Forecast Errors in Public Debt Crises
}

\author{
William Easterly
}

\subsection{Introduction}

It is very well known that growth rates play a role in debt dynamics. Despite this widespread knowledge, real world narratives of public debt crises often focus almost exclusively on budget deficits and neglect the role of growth. This chapter presents the simplest arithmetic possible to illustrate how growth slowdowns could contribute to rapid increases in public debt to GDP ratios. It shows that growth slowdowns have indeed played a role in a wide variety of well-known debt crises. It then considers the implications for precautionary fiscal policy, focusing in particular on conservative forecasts of future growth. Unfortunately, political economy incentives cause policymakers to violate such forecast practices, with a systematic tendency to excessive optimism about future growth.

This chapter updates an analysis in Easterly (2001) of the effect of growth slowdowns on the middle income debt crisis of the 1980s and 1990s, and on the low income debt crisis of the same period (Highly Indebted Poor Coun-

William Easterly is professor of economics at New York University, codirector of the NYU Development Research Institute, and a research associate of the National Bureau of Economic Research.

Thanks to Steven Pennings for superb research assistance and for helpful comments and suggestions. Thanks to the World Bank for kindly providing data on growth forecasts for many countries. Thanks to participants in the NBER conference, "Fiscal Policy after the Crisis," in Milan, December 12-13, 2011, and my discussant Indira Rajaraman This chapter expands greatly upon and draws partially upon an earlier paper, "Fiscal Policy, Debt Crises, and Economic Growth," "International Conference on Economic Policy in Emerging Economies, In Honor of Professor Vittorio Corbo," October 27-28, 2011, Santiago, Chile. Thanks to participants in that conference and my discussant Rodrigo Fuentes for useful suggestions and comments. For acknowledgments, sources of research support, and disclosure of the author's material financial relationships, if any, please see http://www.nber.org/chapters/c12640.ack. 
tries, or HIPCs). Now that it is the rich countries having debt crises, the same methodology will, in this chapter, be applied to discuss the Eurozone debt crises and the debt crisis in the United States.

There are many things this chapter does NOT do. It does not present or test a well-developed theory of fiscal policymaking and policymakers' expectations formation, relying instead on simple arithmetic and descriptive analysis of outcomes. The focus is on medium-run to long-run growth, NOT on cyclical fluctuations or cyclicality of deficits or debt. This chapter does NOT consider managing business cycles. It also considers only the effects running from growth changes to public debt ratios. It does NOT consider any effects running the other way, from fiscal policy to growth. Obviously, these effects deserve consideration, but this chapter omits them to stay focused and a manageable length.

This chapter presents the simple arithmetic of the relationship between growth slowdowns and debt (section 4.2). It shows that this arithmetic indicates an important role for growth in past debt crises in the developing world (HIPC and Latin America in particular), and in the Eurozone and the United States more recently (section 4.3). Section 4.4 finds that when growth forecasts and fiscal policy do not adjust to growth slowdowns, the result is often large forecast errors and budget deficits. Section 4.5 concludes.

The treatment of fiscal arithmetic in section 4.2 considers two views of fiscal sustainability, the first relating to a constant debt-to-GDP ratio (Buiter 1985 and Blanchard 1990), and the second on the forward-looking solvency constraint of the government. ${ }^{1}$ Using the latter approach, Mendoza and Oviedo (2004) find that lower growth rate assumptions can tip otherwise solvent countries in Latin America into insolvency. Huang and Xie (2008) use an endogenous growth model to calculate government solvency conditions, and find that in addition to debt-to-GDP, government expenditure-to-GDP is also needed to characterize fiscal sustainability.

There is a large literature that tests for biases in growth and budget forecasts. Frankel (2011) finds that official growth forecasts across thirty countries tend to be upward biased, and are more biased at longer horizons, during booms, and if the country is part of the Eurozone. For the United States, McNab, Rider, and Wall (2007) find that the US Government's one-year ahead, budget receipts forecasts for fiscal years 1963 through 2003 are biased and inefficient, and the errors are consistent with the political goals of the administration. Auerbach (1994) also finds evidence of bias, though using a longer sample Auerbach (1999) finds less evidence of overall bias (though still finds forecasts are inefficient). Moreover, he finds that official forecasts are no worse than private forecasts. Fredreis and Tatalovich (2000) find evidence of bias in official forecasts for different administrations, with Reagan and Bush administrations being particularly optimistic, and Kennedy, Johnson, and Clinton 
being pessimistic. ${ }^{2}$ Japanese official growth forecasts are biased upwards by 0.7 percentage points (Ashiya 2007), and depending on the period, growth forecasts are biased in either direction for Canada (Mühleisen et al. 2005).

The fiscal issues facing the Eurozone have spurred a series of papers that have found overoptimistic growth and budget forecasts. Strauch, Hallerberg, and von Hagen (2004) finds evidence of biases in some countries, with the cyclical position of the government, and its form of fiscal governance influencing the degree of the bias. Jonung and Larch (2004) find a tendency to overestimate the growth rates in Eurozone countries, with a large bias of about half a percentage point in Germany and Italy. The authors recommend forecasts by independent political bodies. Along these lines, Marinheiro (2011) compares the forecast accuracy of European Commission (EC) forecasts and national government forecasts. He finds that that EC's forecasts are often better (particularly for the year ahead), and argues EC forecasts can be used to reduce optimism bias of national forecasts.

\subsection{Some Unpleasant Fiscal and Growth Arithmetic}

This section considers the simple arithmetic by which debt crises may be provoked or worsened by growth slowdowns. This is meant to be an accounting of how high debt came about, not a theoretical analysis of policymakers' behavior.

\subsubsection{Debt Dynamics}

The simple arithmetic equation for the dynamics of public debt to GDP is extremely well-known. I repeat it here for ease of exposition, giving the version in continuous time.

$$
\begin{aligned}
D & =\text { Public debt in constant prices } \\
Y & =\text { GDP in constant prices } \\
F & =\text { Primary Fiscal Deficit in constant prices } \\
r & =\text { Interest rate on government debt } \\
g & =\text { growth of real GDP } \\
d & =\frac{D}{Y} \\
f & =\frac{F}{Y} \\
\Delta d & =f+(r-g) d .
\end{aligned}
$$

2. Fredreis and Tatalovich (2000) also find that Republican administrations overforecast inflation, and Democratic administrations overforecast unemployment. 
Let $f^{*}$ be the primary fiscal deficit that stabilizes the debt ratio at its current level $d$ (which actually has to be negative in the long run, i.e., a primary surplus, because $r-g$ in the long run is positive). Substituting $f^{*}$ for $f$ in equation (3) will by definition make $\Delta d=0$, so

$$
f^{*}=-(r-g) d .
$$

The determination of $f^{*}$ is still pure arithmetic. I do not mean to imply that it is automatically optimal to stabilize debt at its current level. Equations (3) and (4) hold even if we are considering very short-run debt dynamics, but in the short run, it is obviously necessary to have some discussion of cyclical policy on $f$. As mentioned before, this chapter does NOT consider managing business cycles. As a pure accounting matter, equation (3) still helps us decompose the rise in short-run debt to the part attributable to the primary deficit $f$ and the part attributable to short-run growth $g$, but has nothing to say on whether the rise in debt is suboptimal.

At the other extreme, in the very long run, equations (3) and (4) help us address the well-known long-run budget constraint of the government. Suppose we take $g$ now to be the steady state permanent growth rate, $f$ is the permanent ratio of primary surplus to GDP, and $d$ is the initial debtto-GDP ratio at time zero. Then the long-run budget constraint is that the present value of primary surpluses in the future must be equal to or greater than the current debt:

$$
\int_{0}^{\infty} e^{-r t}(-f) e^{g t} d t \geq d .
$$

When all variables $g, r, f$ (as well as the initial, current debt ratio $d$ ) are constant in the steady state, the simple closed form solution to equation (5) is:

$$
\frac{-f}{r-g} \geq d
$$

Therefore, under these particular assumptions, equation (4) thus gives us the primary surplus $-f^{*}$ that will also satisfy the solvency condition (6). If it seems difficult politically or otherwise to attain this primary surplus, then there is a high risk of default on debt. This is, of course, what is usually meant by "debt crisis."

Now if the permanent growth rate should change, we can discuss how the primary surplus must change in the very long run to keep the government solvent. Note that we must assume in the long run that $r>g$ for the present value of primary surpluses in (5) to be finite.

Of course, how long a period corresponds to the long run is imprecise. I intend for this budget constraint discussion to be illustrative of the idea that the primary surplus must permanently increase in response to any permanent decrease in the growth rate. If it fails to do so, then the debt ratio 
will start increasing. Of course, the latter is still arithmetically true even if we are not sure about whether the long-run budget constraint is relevant.

The bottom line is that the identity (3) is always useful for descriptive accounting of changes in debt ratios and changes in growth rates, regardless of whether we are discussing the short run or long run. We can get closer to normative analysis of how the primary surplus should respond to changes in growth as we move toward the long run in which the solvency condition is relevant.

\subsubsection{Effect of Growth Change if Fiscal Policy Unchanged}

Now suppose that the growth rate $g$ changes. Since we are assessing the possible role of growth rates on debt dynamics, let us go to the extreme case that fiscal policy $f$ stays at its old value set in (4), which keeps the debt ratio stable for the OLD growth rate.

I assume the interest rate also does not change. This assumption is problematic in the final phase of a debt crisis when the market anticipates a risk of default and drives up sovereign borrowing rates. However, I am concentrating on how the debt crisis emerges in the long run, not its final phase of acute crisis.

The initial debt ratio of course does not immediately change either. So the only change in equation (3) is the growth change. Debt dynamics will now depart from the stable debt ratio achieved by (4) in the following amount:

$$
\Delta d=(-\Delta g) d \text {. }
$$

This is the core equation in the chapter; it will form the basis for a number of charts that will have $\Delta d$ on the vertical axis, and $(\Delta g) d$ on the horizontal axis. Given the previous assumptions, this (admittedly simplistic) unpleasant arithmetic of growth predicts a negative slope: that debt ratios will start rising for decreases in growth, and will fall for increases in growth. The larger is the initial debt ratio, the larger will be the rise in the debt ratio for a given change in growth.

In this thought experiment, the primary surplus had been set to the old growth rate to satisfy equation (4) for a stable debt ratio. To evaluate the rise in debt with a growth slowdown, it helps to set out three extreme cases: (a) the growth change was permanent, (b) the old growth rate was temporary but the new one is permanent, (c) the old growth rate was permanent but the new one is temporary. Remember again I am considering ONLY the role of fiscal policy in the long run to avoid debt crises and neglecting all other considerations, such as countercyclical policies. In case (a), the old fiscal policy was appropriate to stabilize the debt, but now must adjust to the new permanent growth rate. In case (b), the old fiscal policy was already incorrect because the old growth rate was not the permanent one, the new growth rate is permanent, and so fiscal policy should again adjust to the new growth 
rate. In case (c), if indeed the new growth rate is temporary, then there is no long-run reason to change fiscal policy.

Of course, in the real world, the new growth rate is unpredictable, and it is difficult to assess whether any growth rate is permanent or temporary. We will discuss evidence for permanent changes in growth using averages for as long a period as possible. We will also discuss mean reversion to consider temporary fluctuations in growth rates.

As already mentioned in the introduction, I am considering the effects of growth on debt crises, and not the reverse. Reverse causality in which debt crises decrease growth (such as the "lost decade" of growth often attributed to the Latin American debt crisis) would simply amplify the negative correlation already predicted in (5).

Even if this chapter abstracts from responses of policymakers, there are also mechanical effects of the growth slowdown on the primary surplus to consider. First, most obviously, if the growth change in the short run is a short-run cyclical phenomenon, there is the well-known effect of recessions increasing deficits and booms lowering them. This chapter is not focusing on such cyclical effects, but they may be too important in the data to ignore, especially in the crisis of 2008 to the present. Second, a growth slowdown may make private borrowers as well as public ones insolvent, possibly leading to bank bailouts with government money (as in the post-2007 crisis). More subtly and returning to thinking more in the medium to long run, if future spending plans were geared to the OLD growth rate (such as through forecasts geared to the old growth rate), while revenue reflects the actual NEW growth rate, then a growth slowdown would increase the deficit. ${ }^{3}$ So this chapter will do some exercises looking at the primary surplus and growth slowdowns.

\subsection{Public Debt Problems and Growth Slowdowns}

This section looks at how much growth slowdowns can account for some well-known debt crises.

\subsubsection{Previous Results: HIPCS and Middle Income Debt Crises of the 1980s}

I showed in an earlier paper (Easterly 2001) that indeed growth slowdowns were strongly associated with rising debt ratios among all developing countries for 1975 to 1994. I reproduce here figure 3 from that paper illustrating those results (figure 4.1).

Figure 4.1 includes two different sets of debt crises - those of low-income

3. This effect is well known in the literature; I am grateful to Steven Pennings for suggesting it be included here. 


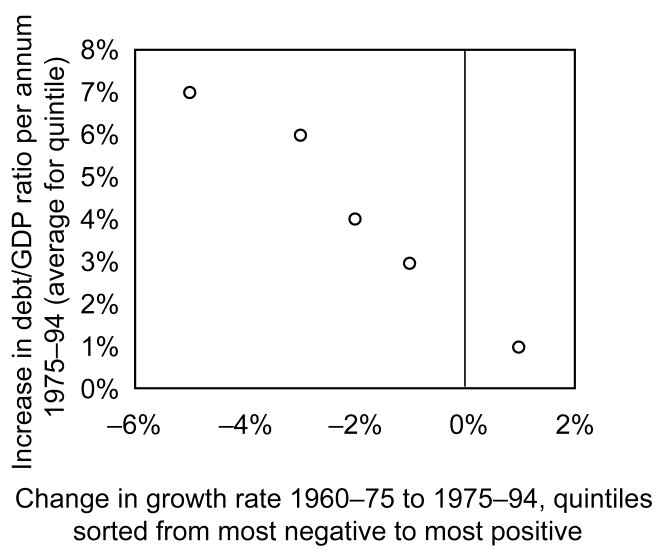

Fig. 4.1 Change in growth and rise in public debt ratio to GDP Source: Reproduction of figure 4.3 from Easterly (2001).

countries and those of middle-income countries (both in the 1980s and early 1990s). The low-income countries eventually got debt relief under the HIPC program of bilateral and multilateral aid agencies. The old paper ran counterfactual exercises in which the debt ratios would have remained stable or even declined if growth had continued at the 1960 to 1975 rate for cases as diverse as Costa Rica, Côte d'Ivoire, Gabon, and Togo, and hence these countries would not have become HIPCs or middle income debt crises. The point is not that it was reasonable to expect the old growth to continue, but that debt crises occurred partly because fiscal policy failed to adjust to the new growth rate.

In the rest of this section, I consider new debt crises that have occurred more recently. The most recent public debt problems are not among the poor countries, but among the rich countries: the Eurozone countries (especially Portugal, Ireland, Italy, Greece, and Spain, the unfortunately named group PIIGS) and the United States.

\subsubsection{Eurozone Debt Crises}

There was indeed a growth slowdown in the Eurozone, as shown in the Figure 4.2 with ten-year moving average growth. ${ }^{4}$ Regarding the PIIGS countries, Greece, Portugal, and Spain had the most severe growth slowdown, after growth in those countries was highest in the Eurozone in the 1960s and early 1970s. Italy went from one of the highest Eurozone growth rates in the 1960 s and early 1970 s to the lowest in the 1990s and 2000s. Ire-

4. I omit more recent entrants into the Eurozone after 2001, which excludes Cyprus, Estonia, Slovakia, and Slovenia. 


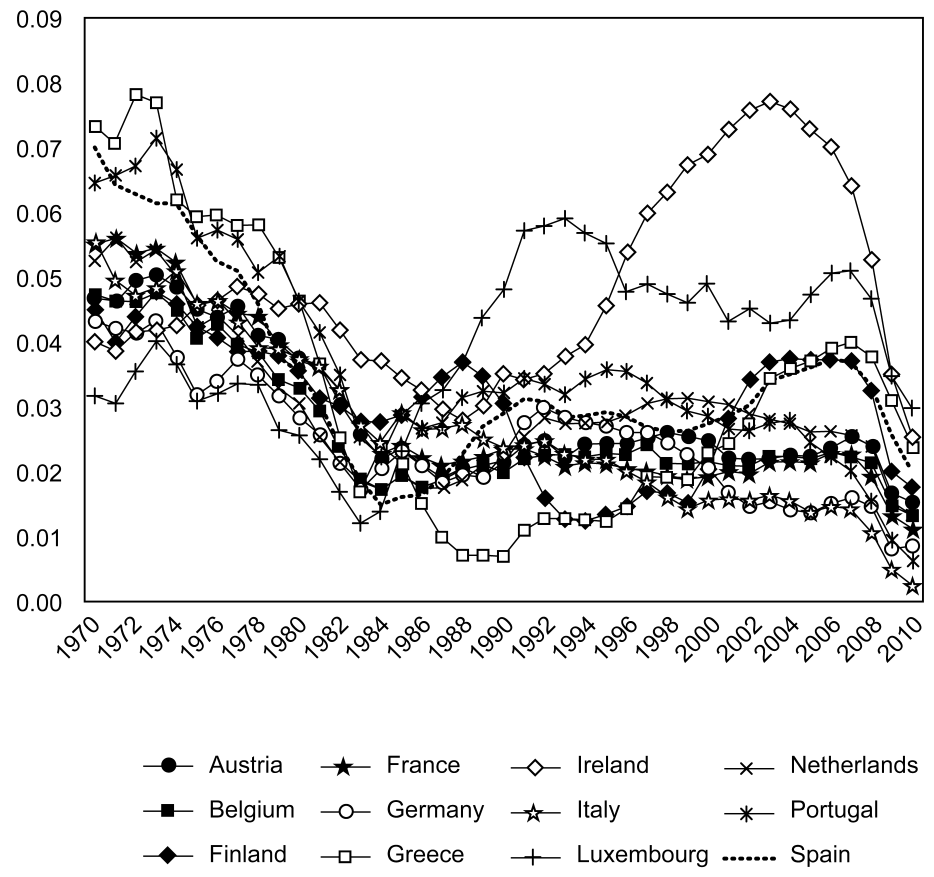

Fig. 4.2 Ten-year moving average GDP growth rate ending in year shown in Eurozone countries

land is atypical, with a growth boom in the 1990s and a collapse in the 2000s. All of the Eurozone countries have a slowdown by 2010 of course, because of the deep crisis in 2007 to 2010, with Portugal and Italy at the bottom.

We can see more evidence for a permanent growth slowdown in a simple fixed effects panel regression for Eurozone countries, in table 4.1. To avoid any endogeneity to the choice of breakpoint, I choose the breakpoint that simply divides the period into two equal subperiods. The growth slowdown is statistically significant for each group, PIIGS and non-PIIGS. There seems to be a strong common element in the slowdown of each group, as we cannot reject the hypothesis of zero fixed effects within each group. The large standard deviation of the pure time-varying error term (assumed to be independent and identically distributed [i.i.d.] in this panel regression) is suggestive that mean reversion will be an important factor in the short to medium run.

Figure 4.3 looks at increases in the debt ratio per annum associated with the growth change from 1960 to 1985 to 1986 to 2010, based on equation (7). The vertical axis is $\Delta d$ (per annum). Note from equation (7) that the larger is the initial debt ratio, the larger will be the predicted increase in the debt ratio associated with growth slowdowns. So the horizontal axis here is the change in growth times the initial debt ratio: $(\Delta g) d$. This graph gives more insight 


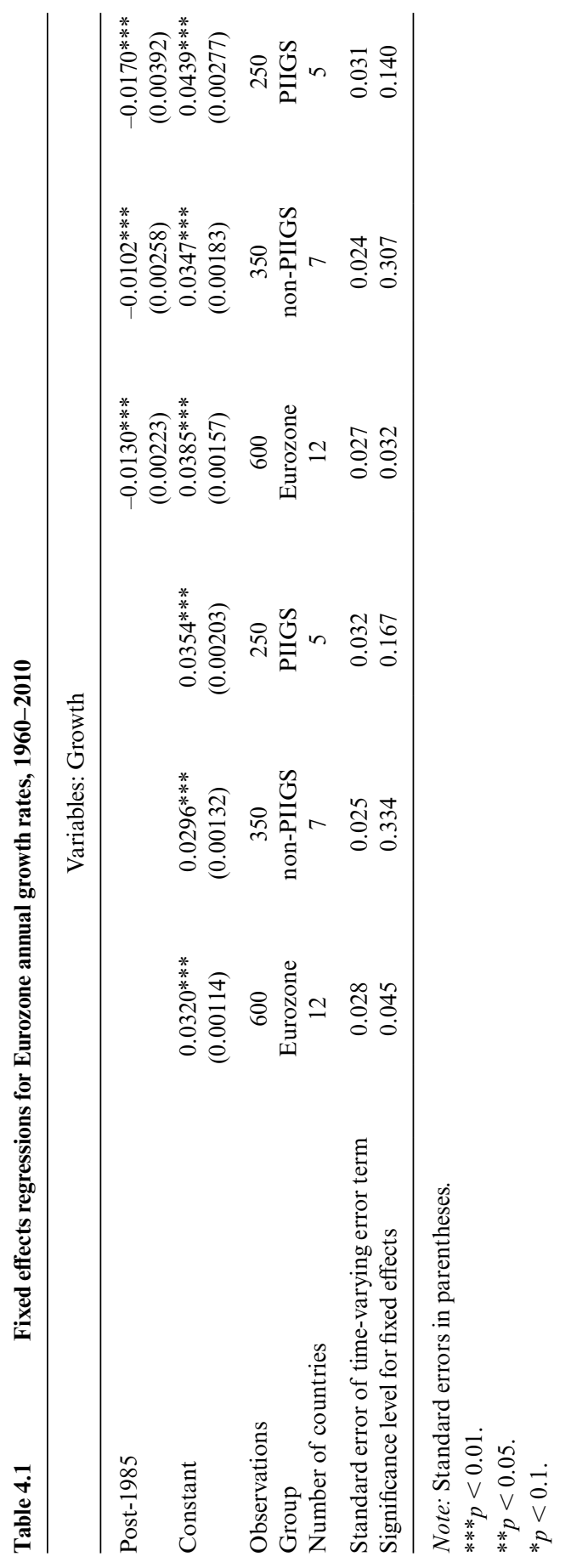




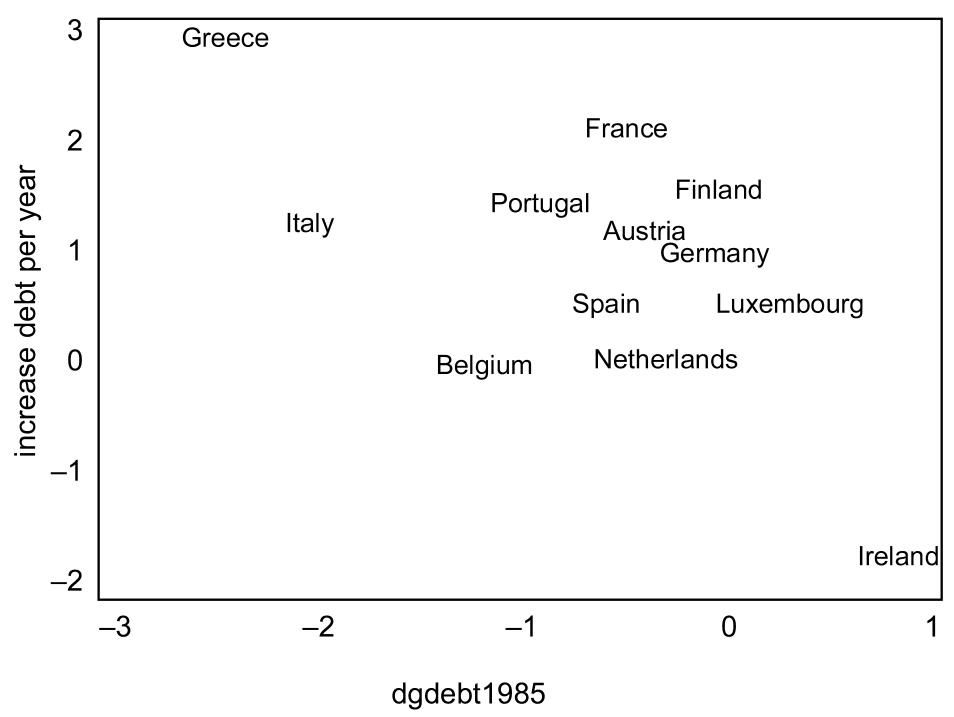

Fig. 4.3 Eurozone countries' growth change, 1960-1985 and 1986-2010 (interacted with initial debt ratio in 1985), and debt ratio increase per year, 1986-2010

into the longer-run debt problems of Greece, Italy, and Portugal among the PIIGS (as well as France!). Ireland actually had debt reduction over this period due to growth acceleration - we will see in the following graph that Ireland's debt changes only show up as associated with growth changes when broken down by decade. Spain did not experience as large a debt increase associated with the growth slowdown.

The previous regression is suggestive that the slowdown was permanent, which suggests a policy failure to adjust the primary balance to the new growth rate. Greece is the most notable example here.

Figure 4.4 looks at the Eurozone countries over the successive decades 1980 s to 1990 s to 2000 s, again based on equation (7) relating $\Delta d$ to $(\Delta g) d$. The horizontal axis thus shows the change in average GDP growth from one decade to the next (interacted with initial debt ratio at the beginning of each decade), and the vertical axis shows the increase in the public debt ratio per annum in the latter decade.

The way to think of these graphs is NOT as a test of significance of the correlation in this one sample alone (which only has twenty-two observations, not to mention the even fewer observations in the previous graph). We are doing debt accounting based on an arithmetic identity, not testing a statistical hypothesis. Rather, the location of points in the upper left-hand corner and lower right-hand corner show episodes where growth changes played an important role in debt changes. 


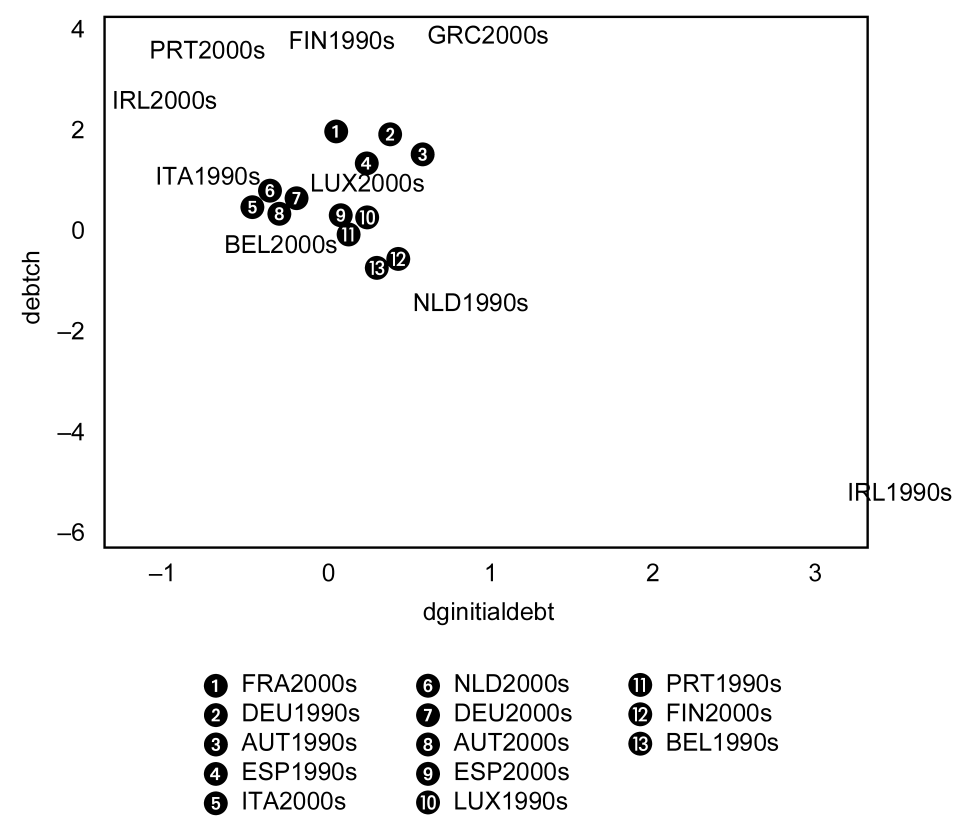

Fig. 4.4 Annualized debt change related to growth change times initial debt, decades of $1990 \mathrm{~s}$ and $2000 \mathrm{~s}$

Portugal is an example of the recent debt crises in which there was a major growth slowdown from 1990 to 2000 to 2000 to 2010. Italy's debt accumulation was associated more with the growth slowdown in the 1990s. One non-PIIGS example of a growth slowdown associated with rising public debt ratios was Finland in the 1990s. With decade averages, there is less confidence about whether growth slowdowns are permanent or temporary.

Ireland is a special case where temporariness is more likely. The boom of the 1990s seems like a temporary deviation from a longer run average. Hence, allowing public debt ratios to fall during 1990 to 2000 with the boom, and then rise after the end of the boom, could be sensible policy as opposed to adjusting fiscal policy to a temporary growth rate. The extent of the public debt rise in 2000 to 2010 may still have been excessive if policymakers expected the high 1990s growth to partially persist; we will revisit this issue with data on projections later.

We suggested earlier that a growth slowdown could also affect the primary surplus. There is some evidence for this in figure 4.5, using five-year averages for growth (change from one five-year average to the next) and the average primary surplus to GDP ratio in the second five-year period. The year part of each point shows the year in which the second five-year period ended. 


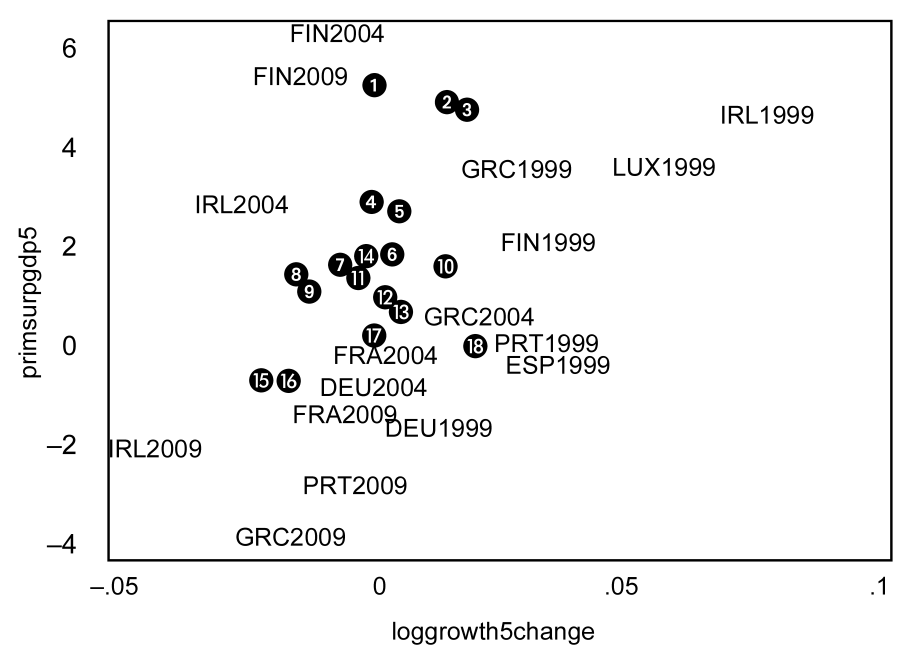

\begin{tabular}{|c|c|c|}
\hline $\begin{array}{ll}\text { (1) } & \text { BEL2004 } \\
\text { (2) } & \text { ITA1999 } \\
\text { (3) } & \text { BEL1999 } \\
\text { 4) } & \text { LUX2004 } \\
\text { 5 } & \text { ITA2004 } \\
\text { 6 } & \text { ESP2004 }\end{array}$ & $\begin{array}{ll}\mathbf{( 7} & \text { LUX2009 } \\
\mathbf{8} & \text { NLD2004 } \\
\text { 9 } & \text { ITA2009 } \\
\text { 10 } & \text { NLD1999 } \\
\text { (1) } & \text { AUT2004 } \\
\text { (2) } & \text { NLD2009 }\end{array}$ & $\begin{array}{ll}\text { (13) } & \text { AUT2009 } \\
\text { (4) } & \text { BEL2009 } \\
\text { (15) } & \text { PRT2004 } \\
\text { (6) } & \text { ESP2009 } \\
\text { (7) } & \text { DEU2009 } \\
\text { (8) } & \text { FRA1999 }\end{array}$ \\
\hline
\end{tabular}

Fig. 4.5 Eurozone growth change and primary surplus/GDP, five-year averages

\subsubsection{US Debt Crisis}

Analysts of the recent crisis with US government debt usually focus on large deficits in the new millennium. Did growth slowdowns have any role in the United States, like they did for some Eurozone countries, the HIPCs, and the 1980s middle income debt crisis?

The federal debt ratio rose steadily for twenty years from 1975 to 1994 (figure 4.6) at the same time that US long-run growth (shown in figure 4.7 as a twenty-year moving average) was slowing down. A very different episode was the decline in the debt ratio during the Clinton years, as growth accelerated in the second half of the 1990s. Finally, the recent climb in US debt ratio corresponds to a collapse of the US growth rate in the new millennium. The 2008 to 2010 crisis was of course very important here, but the growth rate was already decelerating during the George $\mathrm{W}$. Bush years before the crisis.

Next we will analyze growth forecasts made by the administration every year since 1975. These forecasts during most of this period have a six-year horizon, so I also present US data in the current section in rolling sixyear averages.

Figure 4.8 shows the application of equation (7) to the US data, relating $(\Delta d)$ to $(\Delta g) d$. The horizontal axis shows rolling averages for the average growth change from one six-year period to the next, interacted with the 


\section{Debt to GDP}

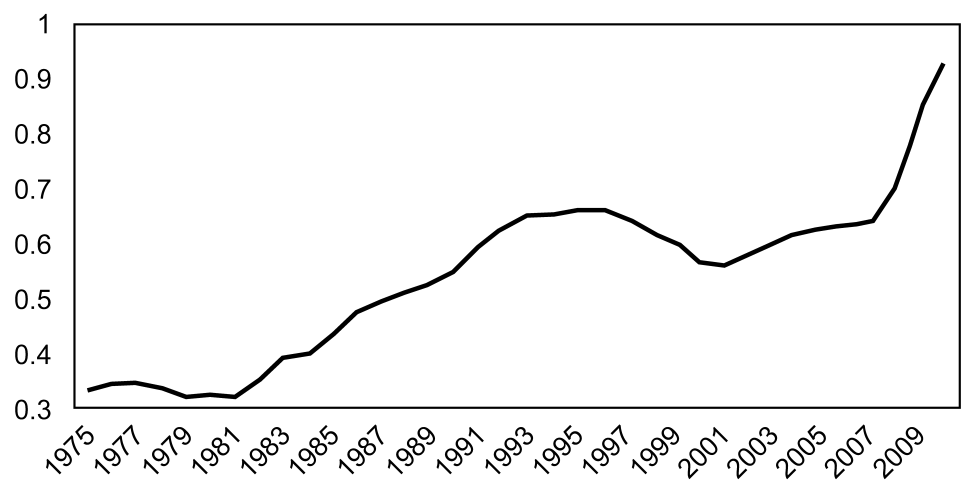

Fig. 4.6 US federal debt to GDP ratio, 1975-2010

20 year Moving Average US GDP Growth Rate (ending in year shown)

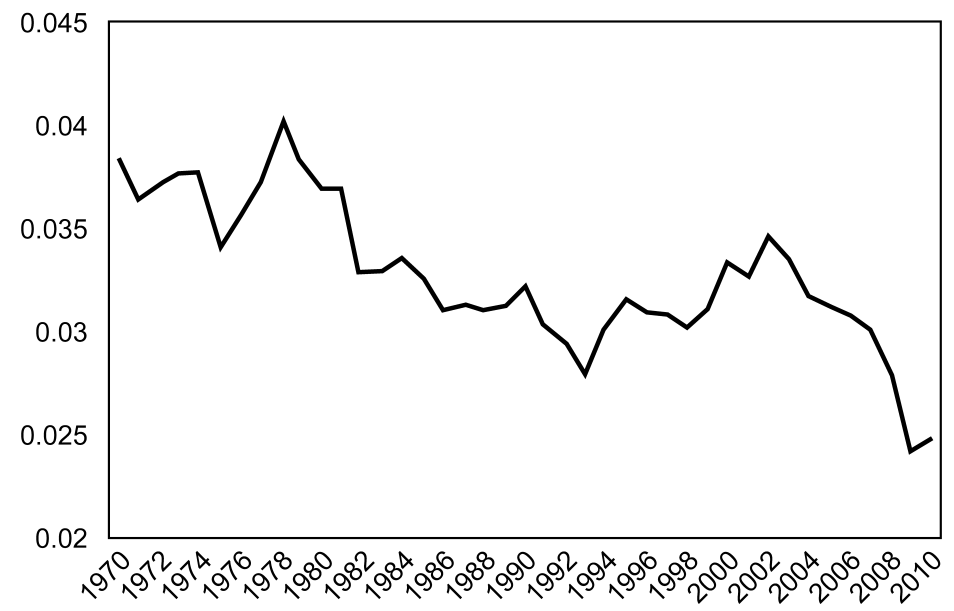

Fig. 4.7 Twenty-year moving average GDP growth rate, United States

initial public debt to GDP ratio at the start of each six-year period on the horizontal axis $((\Delta g) d)$. The vertical axis shows the public debt ratio increase per annum $(\Delta d)$ in the second six-year period, beginning at the start date shown for each point in the graph. Again the purpose of this graph is not statistical testing (there are too few data points and they are not even independent because they are rolling averages) but an illustration of which years have the mechanical growth effect from equation (7) dominant. Growth accelerations in the late 1970s and mid-1990s show strong debt reduction, while growth slowdowns in the new millennium show strong debt increases. 


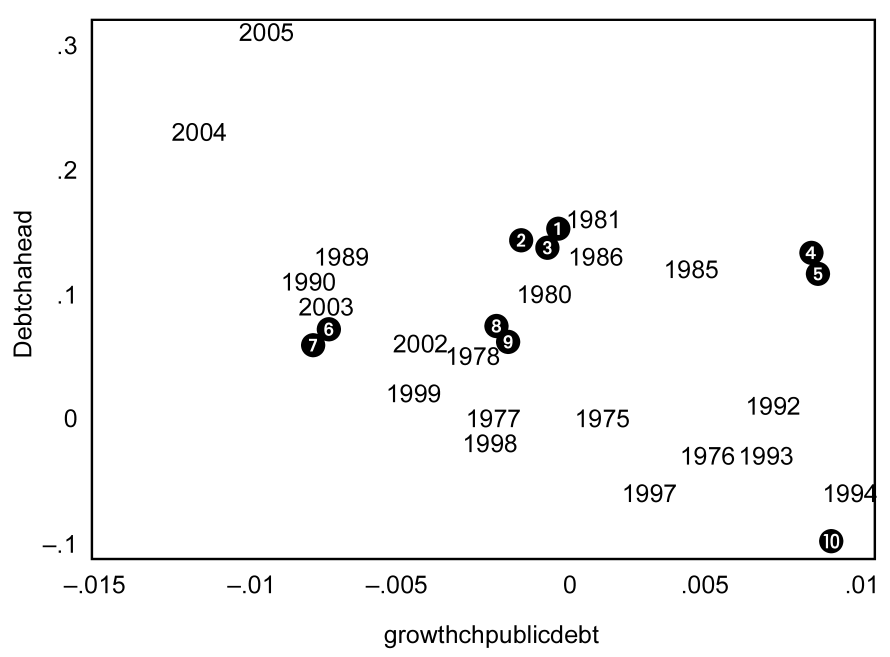

\begin{tabular}{|c|c|c|}
\hline $\begin{array}{ll}\text { (1) } & 1982 \\
\text { 2 } & 1988 \\
\text { 3 } & 1987 \\
\text { (4) } & 1984\end{array}$ & $\begin{array}{ll}\mathbf{5} & 1983 \\
\mathbf{6} & 2001 \\
\mathbf{7} & 2000 \\
\mathbf{8} & 1979\end{array}$ & $\begin{array}{ll}\text { (9) } & 1991 \\
\text { (1) } 1995 ; & 1996\end{array}$ \\
\hline
\end{tabular}

Fig. 4.8 US debt change per annum against change in growth*initial debt ratio, over six years, beginning with start date shown

\subsection{Problems of Growth Projections}

If debt crises can occur partly because of a growth slowdown to which fiscal policy fails to adjust, it may be because the changes are unanticipated or because the change year by year is considered temporary, when it is in fact permanent. We can study these possibilities with actual data we have on growth projections and outcomes. The sensitivity of debt crises to growth slowdowns makes it particularly important to have sound growth forecasting practices. This will give as much lead time as possible to precautionary fiscal policy to avoid debt crises. We will also consider some principles of sound forecasting, such as anticipating regression to the mean and making conservative forecasts when debt is high, and see whether they are observed in this section.

\subsubsection{Association between Growth Changes and Forecast Errors}

Our data on Eurozone growth forecasts comes from countries' budget ministries' submission of projections at the same time as they report budget plans. Unfortunately, these data are very time-consuming to collect and for this chapter it was only possible to collect data on the PIIGS countries in the Eurozone. The projections are for a period between three and five years forward, and began only in 1998. Hence, we have data on projections and 


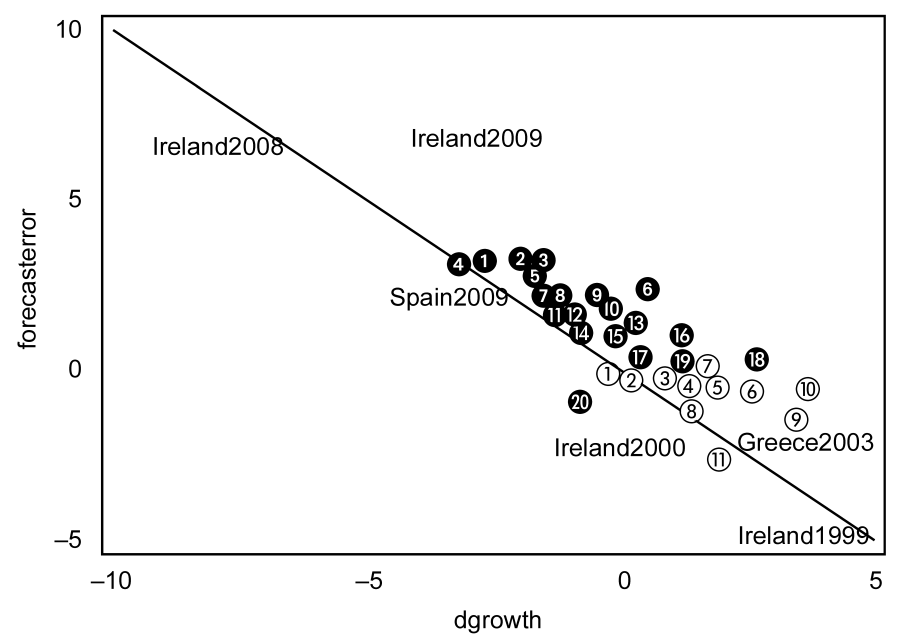
(1) Italy2009
(2) Greece2009
3 Greece2008
(4) Ireland2001
5 Italy2008
6 Italy2003
7 Spain2008
8 Portugal2008
(9) Portugal2003
(10) Italy2002
(1) Portugal2009
(12) Greece2005

$\begin{array}{ll}\text { (3) } & \text { Italy2005 } \\ \text { (4) } & \text { Portugal2001; Italy2001 } \\ \text { (1) } & \text { Portugal2002 } \\ \text { (6) } & \text { Italy1999; Greece2001 } \\ \text { (7) Greece2002 } \\ \text { (8) Italy2004 } \\ \text { (9) Greece1999 } \\ \text { (2) Ireland2003 } \\ \text { (1) Spain2001; Greece2004 } \\ \text { (2) Greece2007; Spain2002; } \\ \text { Ireland2006; Portugal1999; } \\ \text { Portugal2005 }\end{array}$

(3) Spain2007; Italy2007; Portugal2000

(4) Ireland2007; Spain2004 Spain2006; Spain2005

(5) Portugal2007; Portugal2006

(6) Italy2006; Ireland2005

(7) Spain2003; Greece2000

(8) Ireland2004; Spain2000; Spain 1999

(9) Greece2006; Italy2000

(10) Portugal2004

(11) Ireland2002

Fig. 4.9 PIIGS countries, change in growth and forecast error at horizon $t+1$

actual outcomes for the period 1999 to 2010 for the PIIGS countries. The first thing to document is the unsurprising link between growth changes and forecast errors.

Figure 4.9 shows the association between forecast errors (projected GDP for $t+1-$ actual GDP growth at $t+1$ ) at horizon $t+1$ and the change in growth from $t$ to $t+1$. There is indeed an association between declines in growth and positive forecast errors, as well as examples of negative forecast errors when growth accelerates. The slope will be -1 if the growth forecast was simply for the previous growth to continue (the graph shows a line with slope -1 for reference). In the presence of mean reversion (strongly confirmed by tests on growth rates in this sample and in others), predicting the same growth rate to continue fails to utilize information on mean reversion. If the current growth rate is above the long-run average, then forecasts should anticipate a movement back down toward the mean.

Figure 4.10 shows the growth changes and forecast errors for the time 


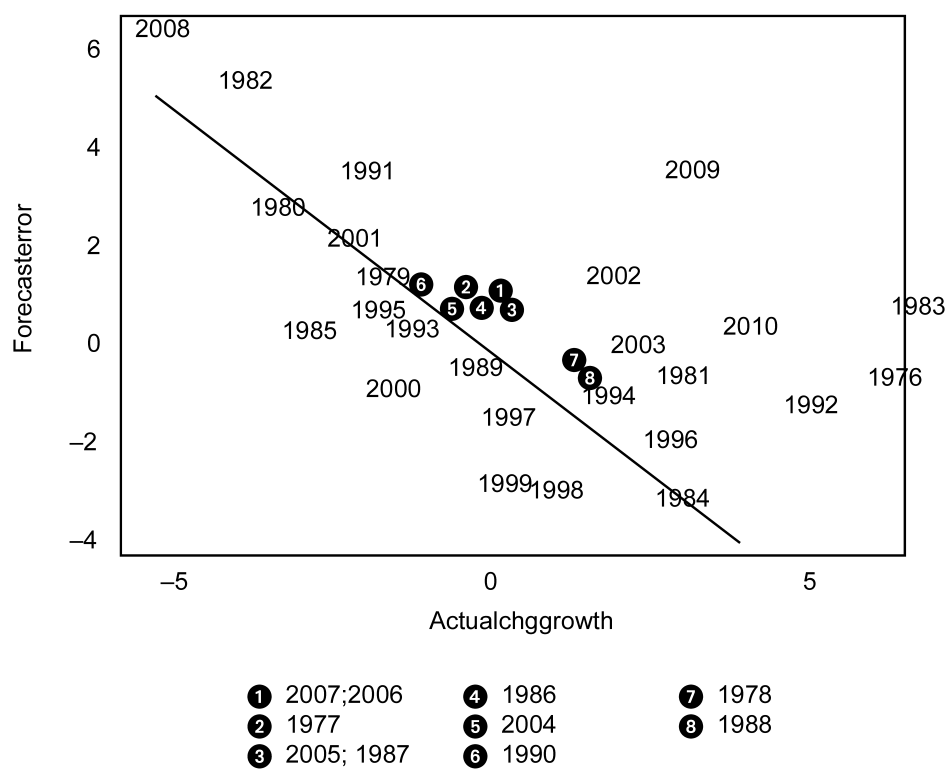

Fig. 4.10 US annual data, forecast error, and actual change in GDP growth at horizon $t+1$

series for the United States for 1975 to 2010 for every year at horizon $t+1$. Again, unsurprisingly, large growth changes produce forecast errors in the opposite direction. The line drawn shows the reference case of a slope of -1 , in which the forecast is simply for the current growth to continue unchanged.

\subsubsection{Association between Forecast Error and Debt Change and Deficits}

Another way to show the role of growth changes in debt is to show the link directly from the forecast error to the change in the public debt ratio. Figure 4.11 shows positive forecast errors and negative forecast errors important for some debt changes for the PIIGS countries. A similar graph (figure 4.12) shows episodes of positive forecast errors associated with debt increases in the United States, while negative forecast errors are associated with debt decreases (here using the rolling six-year forward projections).

\subsubsection{Sound Forecasting Practices and Reality}

As previously suggested, countries that already have high debt are more sensitive to growth slowdowns. It makes sense that the higher is the initial debt, the more conservative should be the growth forecasts. In the Eurozone, the high debt countries should be more conservative about forecasts, and the United States should have been more conservative as the debt ratio got higher. We also have data on projections made for HIPC countries as an 

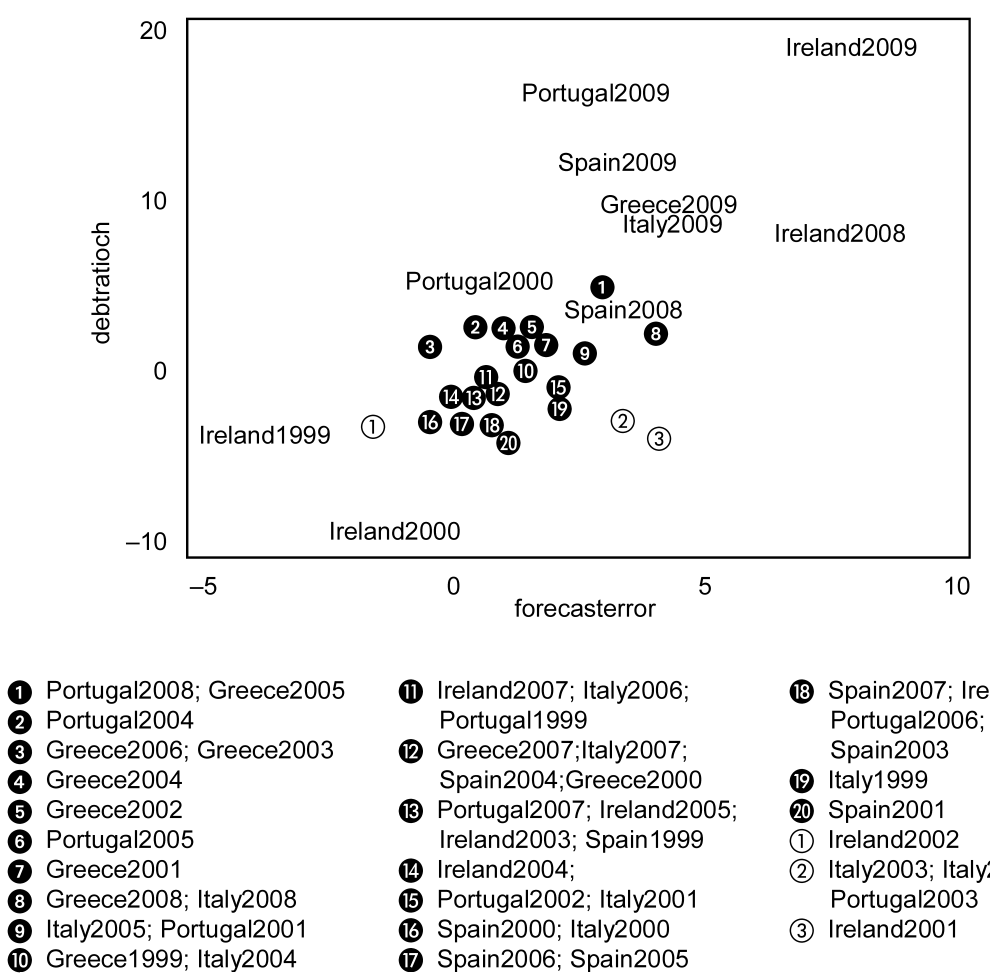

(11 Ireland2007; Italy2006; Portugal1999

(12) Greece2007; Italy2007; Spain2004;Greece2000

(13) Portugal2007; Ireland2005; Ireland2003; Spain1999

(14) Ireland2004;

(15 Portugal2002; Italy2001

16 Spain2000; Italy2000

17 Spain2006; Spain2005
18 Spain2007; Ireland2006; Portugal2006; Spain2002; Spain2003

(19) Italy1999

(20) Spain2001

(1) Ireland2002

(2) Italy2003; Italy2002; Portugal2003

(3) Ireland2001

Fig. 4.11 GDP growth forecast error for $t+1$ and public debt to GDP ratio change in that year

interesting post-debt-crisis example, where conservative forecasts could have helped to prevent reemergence of new debt crises.

The consideration of mean reversion should also play a role. High growth well above the countries' long-run average should not be expected to continue when projections are made. We have already seen in figures 4.9 and 4.10 a failure to utilize mean reversion.

Of course, projections are not made by disinterested parties. It may be tempting for politicians to use optimistic projections to disguise the reality of debt problems and postpone the need for fiscal adjustment. The HIPC example will show an unusual case of this. Politicians may find it tempting to treat low growth as temporary and high growth as permanent, and so may not sufficiently anticipate growth slowdowns from temporary highs.

HIPCS

Highly Indebted Poor Countries became HIPCs because in many cases they failed to adjust to the growth slowdown. In other cases, growth played 


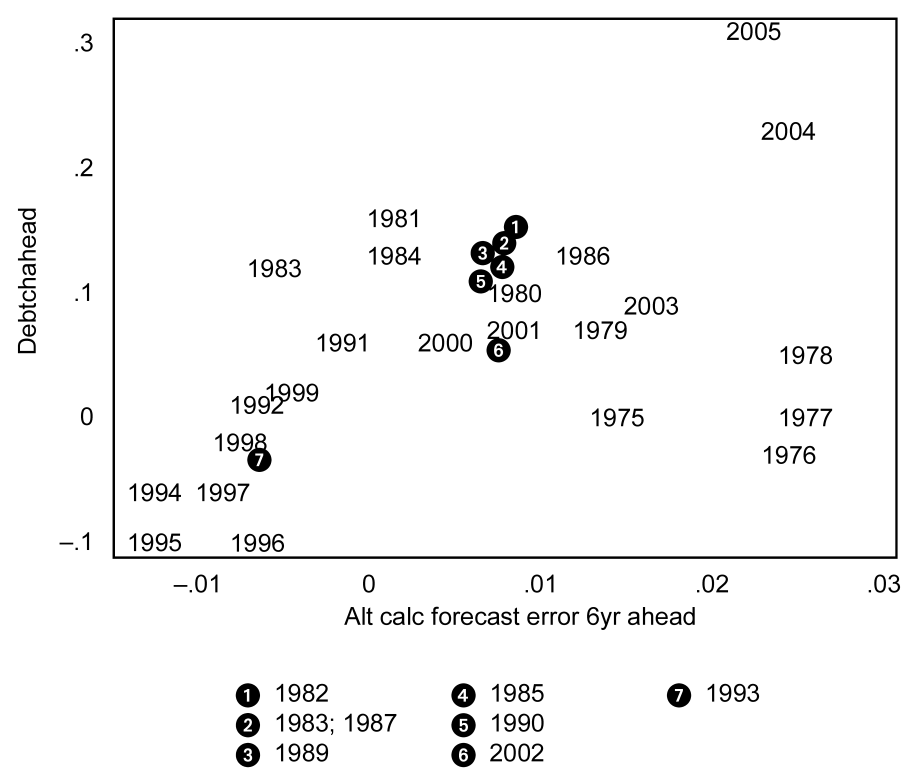

Fig. 4.12 US debt ratio change per annum and US GDP growth forecast error, over six years ahead, with start date shown

a smaller role or no role, and the HIPCs simply ran excessive deficits to accumulate high debt relative to GDP. In either case it would seem to suggest that the HIPCs would need to do fiscal adjustment along with receiving debt relief to prevent the emergence of new debt crises all over again.

However, the HIPC program was determined in part by an international political campaign to grant debt forgiveness to poor countries. This campaign applied pressure not only to forgive the debts but also to maintain the same flow of official financing to poor countries (which partly consisted of loans and not just grants) and to NOT otherwise reduce public spending, which implied NOT doing any major fiscal adjustment in HIPC countries. A fiscal policy unchanged from one that previously created a debt crisis would eventually result in the emergence of new debt problems. The World Bank and International Monetary Fund (IMF) analysts who designed HIPC debt relief packages were required to do long-run debt and growth forecasts to demonstrate that the HIPCs debt after relief was "sustainable"- that is, debt ratios would not increase again in the future.

How to reconcile these irreconcilable mandates? The answer appears in the next table: official HIPC programs prepared by IMF and World Bank staff exaggerated future growth prospects of the HIPCs. I gained access to a large database of growth forecasts in HIPC documents produced in the 1990s and early 2000s. I was also given growth forecasts made for non-HIPC countries for the same time periods by World Bank and IMF staff. Now that 
Table 4.2

Regression of annual growth forecast errors ("ForecastErr") and dummies for HIPC countries ("HIPC") and sub-Saharan Africa ("Africa"), 1995-2010

\begin{tabular}{lccc}
\hline & \multicolumn{3}{c}{ ForecastErr } \\
\cline { 2 - 4 } Variables & $(1)$ & $(2)$ & $(3)$ \\
\hline Africa & 0.145 & & 0.605 \\
& $(0.394)$ & $1.022^{* * *}$ & $(0.367)$ \\
HIPC & $0.954^{* *}$ & $(0.343)$ & \\
& $(0.380)$ & 0.0111 & 0.152 \\
Constant & -0.0416 & $(0.271)$ & $(0.298)$ \\
& $(0.307)$ & 156 & 156 \\
Observations & 156 & 0.054 & 0.018 \\
$R^{2}$ & 0.055 & & \\
\hline
\end{tabular}

Note: Robust standard errors in parentheses.

$* * * p<0.01$.

$* * p<0.05$.

$* p<0.1$.

I have access to actual growth data up through 2010, I can calculate the ex post forecast errors (ForecastErr in the regressions shown following) in both groups. There is a significant positive forecast error of HIPC countries of about 1 percentage point of growth relative to non-HIPC countries. These results are even more surprising when we consider the positive shocks to many HIPCs through commodity prices and growth rates in 2000 to 2010 that were at historic highs for other reasons. Although many HIPC countries are in Africa, the results are not a spurious consequence of excessive optimism about Africa (there is indeed no evidence for the latter (see table 4.2). To avoid the unpalatable expectation that debt ratios will start climbing again in the absence of fiscal adjustment in HIPCs (although from very low levels after debt forgiveness took effect in recent years), the analysts apparently resorted to high growth forecasts. A situation that called for conservative growth forecasts - countries with a long track record of fiscal mismanagement - instead generated the reverse.

\section{PIIGS over 1999 to 2010}

Were the PIIGS conservative on their growth forecasts because of their precarious debt situations? Or did they use optimistic growth forecasts as a way to cover up their fiscal problems? For example, the European Commission commented diplomatically on a Greek forecast in 2001:

The macroeconomic projections included in the stability programme, indicating strong real GDP growth, are considered as ambitious, at the upper level of possibilities. ("Commission Assesses the 2000 Stability Pro- 
Table 4.3

Significance of forecast errors, annual data for PIIGS countries, 1999-2010

\begin{tabular}{lcccc}
\hline Dependent Variable: & $\begin{array}{c}\text { Forecast error } \\
\text { for growth }\end{array}$ & $\begin{array}{c}\text { Forecast error } \\
\text { for growth }\end{array}$ & $\begin{array}{c}\text { Forecast error } \\
\text { for growth }\end{array}$ & $\begin{array}{c}\text { Forecast error } \\
\text { for growth }\end{array}$ \\
\hline Average & $1.286^{* * *}$ & $1.286^{* * *}$ & $1.286^{* *}$ & \\
Portugal & $(0.182)$ & $(0.25)$ & $(0.426)$ & $1.699^{* * *}$ \\
& & & $(0.271)$ \\
Ireland & & & $1.367^{*}$ \\
Italy & & & $(0.712)$ \\
Greece & & & $1.731^{* * *}$ \\
Spain & & & $(0.304)$ \\
& & & $1.142^{* * *}$ \\
Observations & & & $(0.43)$ \\
$R^{2}$ & & & 0.434 \\
Standard errors clustered by & Country & Year forecast & $(0.299)$ \\
& & was made & 193 \\
\hline
\end{tabular}

Note: Robust standard errors in parentheses.

$* * * p<0.01$.

$* * p<0.05$.

$* p<0.1$.

gramme for Greece (2000-2004)", European Commission press release, January 24, 2001, available at http://europa.eu/rapid/searchAction.do)

Table 4.3 shows the average forecast errors for the PIIGS sample over 1999 to 2010 .

The forecast errors for the PIIGS over 1999 to 2010 were significantly positive on average. This result survives clustering the errors by the date of the forecast, or alternatively clustering by country. A simple sign test of whether forecast errors were positive also confirms the significance at the 1 percent level.

The result is not entirely driven by the crisis period 2008 to 2010 . The PIIGS' average forecast error is much smaller ( 0.31 percentage point per annum) over 1999 to 2007, but both the average error test and the sign test are still significant at 5 percent for positive forecast errors (not shown). Moreover, even if the depth of the crisis was unusual, a recession at some point during a twelve-year period is NOT unusual, so it biases things the other way to endogenously exclude the bad years.

Looking at individual countries' forecast errors, those for Portugal, Italy, and Greece are large and statistically significant at the 1 percent level, Ireland is large but only significant at the 10 percent level, and Spain's forecast 


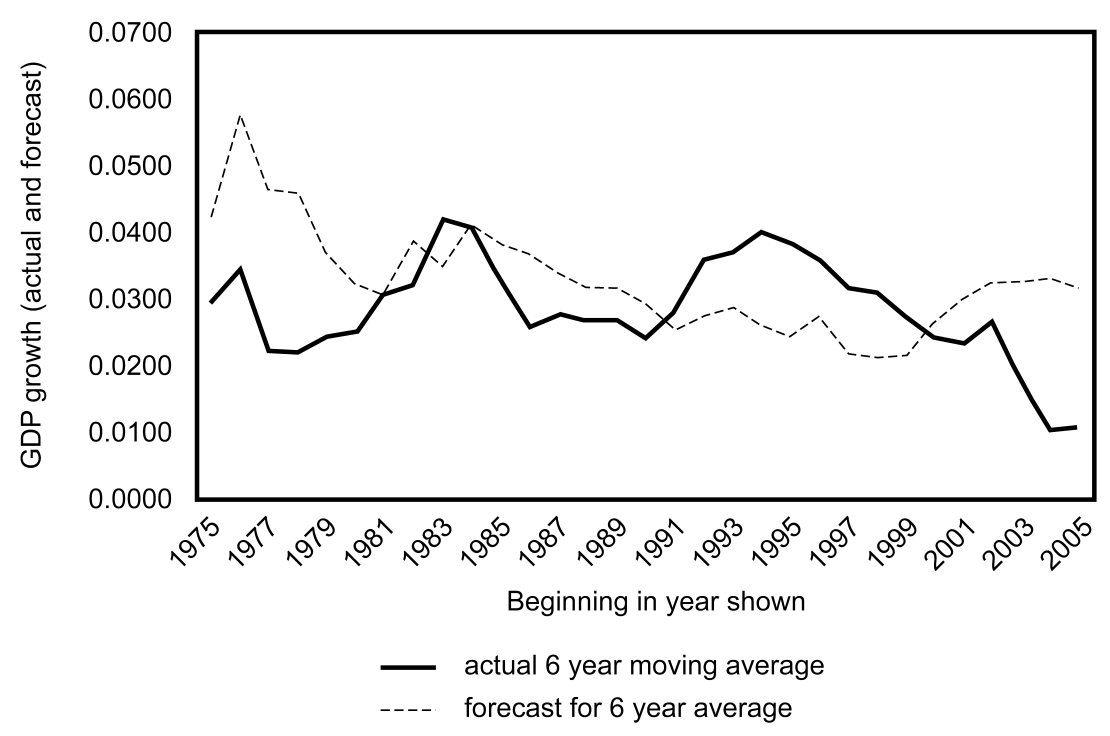

Fig. 4.13 Forecast and actual six-year moving average growth in United States

error is smaller and not statistically significant. The worst offenders against the maxim of being conservative when debt is already high were Italy and Greece, whose debt was already above 100 percent of GDP in 1998, yet forecasts over 1999 to 2010 were still too optimistic. Greece was also the worst offender against the principle of mean reverting forecasts, as the average growth projected for 1999 to 2010 was well above its previous long-run growth rate.

\section{The United States during the New Millennium}

Figure 4.13 shows the forecast and actual US GDP growth as six-year moving averages, going forward from the date shown. The excess optimism in the late 1970s was not that damaging because debt levels were not high. The conservative forecasts in the 1990s at higher debt levels contributed to the reduction in the debt ratio, as noted previously.

The final curious episode is the increase in projected growth even as the actual growth rate was falling, beginning at the new millennium (figure 4.13). This began before the effects of the financial crisis would be included in sixyear-forward growth. This was the opposite of sound forecasting practice, which should have anticipated the reversion to the mean after the boom of the 1990s (that did, in fact, happen).

One possible interpretation is that negative fiscal shocks after $9 / 11$ - such as the spending associated with two new wars-led to anticipated increases in the deficit. To avoid showing a projected rise in debt ratios, the administra- 
tion simply raised the projected growth rate. This was part of the complex of problems that contributed to the debt crisis the United States has today.

\subsection{Conclusion}

The unpleasant arithmetic of growth and public debt is that permanent growth slowdowns call for fiscal adjustments that (as in many examples shown here) politicians are unwilling or unable to make. As a result, debt crises often result in part from major growth slowdowns, a factor that has been underemphasized in the literature and in public discussion compared to the emphasis on budget deficits. This unpleasant arithmetic suggests the important benefits of forecasting of growth that acknowledges mean reversion and is more conservative the more precarious the debt situation. Unfortunately, political economy factors seem to result in analysts sometimes doing the reverse - making growth forecasts more optimistic to disguise the need for fiscal adjustment.

\section{References}

Ashiya, Mashahiro. 2007. "Forecast Accuracy of the Japanese Government: Its Year-Ahead GDP Forecast is Too Optimistic." Japan and the World Economy 19 (1): $68-85$.

Auerbach, Alan J. 1994. "The US Fiscal Problem: Where We are, How We Got Here and Where We're Going." NBER Macroeconomics Annual 1994, vol. 9, edited by Stanley Fischer and Julio J. Rotemberg, 141-75. Cambridge, MA: MIT Press.

. 1999. "On the Performance and Use of Government Revenue Forecasts." National Tax Journal 52 (4): 765-82.

Blanchard, Olivier J. 1990. "Suggestions for a New Set of Fiscal Indicators." OECD Working Paper no. 79. Paris: Organization for Economic Cooperation and Development.

Buiter, Willem H. 1985. "Guide to Public Sector Debt and Deficits." Economic Policy: A European Forum 1 November:13-79.

Chalk, R., and R. Hemming. 2000. "Assessing Fiscal Sustainability in Theory and Practice.” IMF Working Paper no. 00/81. Washington, DC: International Monetary Fund.

Easterly, William. 2001. "Growth Implosions and Debt Explosions: Do Growth Slowdowns Explain Public Debt Crises?” Contributions to Macroeconomics 1(1). http://williameasterly.files.wordpress.com/2010/08/29_easterly_growthimplosions anddebtexplosions_prp.pdf.

Frankel, J. 2011. "Over-optimism in Forecasts by Official Budget Agencies and Its Implications." NBER Working Paper no. 17239. Cambridge, MA: National Bureau of Economic Research, July.

Frendreis, John, and Raymond Tatalovich. 2000. "Accuracy and Bias in Macroeconomic Forecasting by the Administration, the $\mathrm{CBO}$, and the Federal Reserve Board." Polity 32 (4): 623-32.

Huang, H., and D. Xie. 2008. "Fiscal Sustainability and Fiscal Soundness." Annals of Economics and Finance 9-2:239-51. 
Jonung, Lars, and Martin Larch. 2004. "Improving Fiscal Policy in the EU: The Case for Independent Forecasts.” European Commission Economic Paper no. 210.

Marinheiro, C. 2011. "Fiscal Sustainability and the Accuracy of Macroeconomic Forecasts: Do Supranational Forecasts Rather than Government Forecasts Make a Difference?" Journal of Sustainable Economy 3 (2): 185-209.

McNab, Robert M., Mark Rider, and Kent Wall. 2007. "Are Errors in Official US Budget Receipts Forecasts Just Noise?" Andrew Young School Research Paper Series Working Paper no. 07-22, April.

Mendoza, E., and P. M. Oviedo. 2004. "Public Debt, Fiscal Solvency and Macroeconomic Uncertainty in Latin America: The Cases of Brazil, Colombia, Costa Rica, and Mexico.” NBER Working Paper no. 10637. Cambridge, MA: National Bureau of Economic Research, July.

Mühleisen, Martin, Stephan Danninger, David Hauner, Kornélia Krajnyák, and Bennett Sutton. 2005. "How Do Canadian Budget Forecasts Compare with Those of Other Industrial Countries?" IMF Working Papers no. 05/66, April. Washington, DC: International Monetary Fund.

Strauch, R., M. Hallerberg, and J. von Hagen. 2004. "Budgetary Forecasts in Europe-The Track Record of Stability and Convergance Programs." European Central Bank Working Paper no. 307.

\section{Comment Indira Rajaraman}

This chapter by William Easterly explores the possible contribution of technocratic error in growth projections toward the entire range of modernday debt crises, from those in Latin American and Highly Indebted Poor Countries (HIPC) in the 1980s and 1990s, to the debt-stressed countries of the Eurozone today. The chapter is not about unforeseen adverse growth shocks. It is about systematic upward bias in official growth forecasts over the medium to long run, and is essentially descriptive in its linking of that bias to the fiscally unsustainable debt outcome, normalized by the (lower) realized GDP denominator.

The chapter adds to what is by now a fairly extensive literature on growth forecast error covering the United States, Canada, Japan, and the Eurozone. Systematic upward bias is reported in these prior studies for Japan (Ashiya 2007), and more generally for a set of thirty Organization for Economic Cooperation and Development (OECD) countries, with higher bias at longer horizons, and for membership of the Eurozone (Frankel 2011). A recent interesting paper by Marinheiro (2010) finds national forecasts of Eurozone members to be more biased upwards than European Commission forecasts.

I have five comments on the chapter by Easterly.

Indira Rajaraman is honorary visiting professor at the Indian Statistical Institute and a member of the Central Board of Directors and of the Technical Advisory Committee on Monetary Policy of the Reserve Bank of India.

For acknowledgments, sources of research support, and disclosure of the author's material financial relationships, if any, please see http://www.nber.org/chapters/c12641.ack. 